\title{
JONATÁS Y MANUELA: \\ LA HISTORIA DE UNA AMISTAD TRANSNACIONAL Y ÉTNICA
}

\author{
POR \\ MARIA ZIELINA \\ California State University
}

En 1994, a tan solo tres años de haber publicado su primera novela Bajo la piel de los tambores (1991), vuelve Luz Argentina Chiriboga a adentrarse en la subjetividad del retrato funcional de las desigualdades sociales. Esta vez nos ofrece una exploración de la relaciones interraciales y los esquemas de vida compartidos entre dos mujeres ecuatorianas, en este caso los de Jonatás y Manuela, cuyas diferencias de clase y raza no se convirtieron en obstáculos de ninguna clase para evitar su hermanamiento.

Son precisamente los nombres de estos dos personajes, el de la ama y la esclava, los que le dan título a la novela, nombres que han sido bien barajados diacrónicamente en las innumerables historias publicadas sobre la vida de Simón Bolívar, pero bien ignorados a la hora de proponerse textos con características de épica ecuatoriana. De facto es que los diarios de Manuela Saenz, rescatados del olvido no hace tanto tiempo, solo vinieron a alcanzar la categoría de textos multidimensionales a partir de los últimos diez años.

Las historiografías escritas sobre Simón Bolívar nos dejan observar la seducción que tenían los historiadores y biógrafos por las hazañas del héroe; seducción que no ha disminuido, como lo demuestra la novela de García Márquez, cuya estructura de épica nacional hegemónica se olvidó de presentar a la "libertadora del Libertador". Pudiera decirse que algunas de las novelas latinoamericanas, de corte nacional, son el resultado del embelesamiento que sienten los autores frente a los próceres y aunque las mismas tienen éxito en lo que se refiere al entronizamiento del nacionalismo romántico, o sea con respecto al material épico que se ficcionaliza, fallan por su limitación en estabilizar la relación entre la conducta del héroe y la anécdota de la cotidianeidad, el de vivir intercultural e intraracialmente relacionado con otros sujetos que están haciendo histoires. ${ }^{1}$ Este tipo de novelas se quedan parcas a la hora de estabilizar las cualidades del discurso hegemónico, el que muchas veces en su privilegiada estructura de discurso nacional, relega a la ignominia o al olvido la enunciación de otros diversos "yo", incluyendo los de la mujer, el negro y el indio. El diseño del discurso nacional que se ha llevado hasta ahora, por lo general, no engloba de forma balanceada o equitativa, el principio de responder directamente a la valoración y jerarquización que se le da a las mujeres y grupos étnicos que componen la

\footnotetext{
'Me estoy refiriendo al sentido que le dio Gerard Genette al término pues aquí el contacto entre Bolívar y la criolla supone también minicontactos entre éste y Jonatás, y consecuentemente, el de ambas con la historia de Bolívar, con la política de la época y las circunstancias de la guerra.
} 
sociedad que se intenta ficcionalizar, y se crea la apariencia de que existe una cultura nacional hegemónica. Muchas de las narraciones latinoamericanas de corte nacional se estructuran en un solo tipo: las de "narración hegemónica — diacrónica". ${ }^{2}$

Observando y leyendo todo lo que se ha escrito sobre El Libertador de América, pudiera afirmarse que Bolívar ha sido una de las figuras que ha gozado de gran preferencia entre biógrafos e historiadores, y su corta y hazañosa vida es usada para ejemplificar los desafueros e injusticias que se cometieron durante la América colonial, con la ventaja de que al hacerlo no tienen o tuvieron que mencionar las que se habían cometido contra Manuela. La historiografía de Manuela Saenz es semejante a la historiografía de otras mujeres latinoamericanas que vivieron en los pasados siglos y a principios de éste; ésta es un metarrelato que gira más de una vez alrededor de diversos minimetarrelatos, como son los del nacionalismo, las intrigas políticas, las diferencias de clases, el amor, el racismo y el prejuicio. Tal y como sucede con las de otros países, la historiografía de esta mujer, desinhibida y rebelde, revela la compleja interrelación que cada uno de estos minimetarrelatos tuvieron en la formación del discurso nacional de la Gran Colombia; minimetarrelatos, a veces ingenuos, que delatan interpretaciones subjetivas y hegemónicas y que impactaron no sólo la vida de Manuela y Simón y Jonatás sino la perspectiva histórica de muchos historiadores en el presente y pasado siglo. A través de estos "relatos" nos llegó una Manuela sin pedestal, atrapada entre las "cartas de El Libertador", un nombre más entre las decenas de nombres, una amante más entre las amantes.

Al leerse las reflexiones de la Saenz descubrimos que su vida y la de Jonatás tienen dimensiones tan ricas en su asentamiento de la realidad que escapa al "frío" planteamiento de la biografía restringida, que se necesita de otra forma, más flexible y dinámica que permita oir las voces de estas dos mujeres. Al general Antonio de la Guerra cupo el honor de intuir que los diarios de la quiteña encerraban diversas y complejas histoires, las cuales enriquecerían las crónicas y documentos dejados por Bolívar y crearían tensiones con los textos que se publicaban con respecto al emancipador de América. Pero si aceptamos que la perspectiva que nos arroja Manuela sobre su relación con su amante-héroe es "histoire", texto multidimensional que hace de la historia un sujeto historiado, tenemos que aceptar que la que hubo entre Jonatás y la quiteña alcanza la misma categoría. Por eso, si discurrimos sobre la praxis de la militancia de la criolla en las filas revolucionarias necesitamos discurrir en torno a la innegable negociación de identidad que tuvo que llevar a cabo Jonatás para enfrentarse desde muy pequeña a su realidad de esclava-soldado-amiga. Si nos sorprendemos de la entereza de Manuela frente al destierro y la pobreza, tenemos que sorprendernos también de la que exhibió esta mujer negra al acompañarla. Si admiramos a Manuela por su fidelidad a la memoria del amante y su reticencia a hablar sobre éste, aún después de haber pasado más de veinte años de su muerte, tenemos que admirar a Jonatás por su fidelidad en permanecer con la linda criolla, cuando ya todo el mundo parecía haberse olvidado de las melodías que la guapa hija del Regidor de Quito había bailado con El Libertador de América, en 1822 .

\footnotetext{
${ }^{2}$ Diacrónica porque siempre está oscilando entre dobles, entre dos versiones: la historia oficial y la no oficial.
} 
No es hasta hace muy poco que la leyenda heroica de Manuela aparece en la narrativa latinoamericana, y como es de suponer, el acceso público a sus diarios ha despertado la curiosidad de escritores y críticos, sobre todo de las escritoras, quienes se afanan en presentarnos un retrato de la quiteña a través de sus escritos A esta presentaciones no le son ajenas ni las cualidades de la estética de la biografía ni el dramatismo que el género testimonial brinda a la historia. Este tipo de retrato nos lo brindan Patriota y amante de Ud.; Manuela Saenz: el último amor de Simón Bolivar, ${ }^{3}$ y Jonatás y Manuela, la novela de Luz Chiriboga, la cual ha acaparado nuestro acercamiento crítico.

En Jonatás y Manuela, la figura de estas dos mujeres es revivida poniendo como fondo narrativo la subcultura de la guerra de independencia suramericana, cuyos dramáticos aconteceres revelan el surgimiento y desarrollo de condiciones y relaciones sociopolíticas antagónicas que no desaparecieron una vez que se acallaron los disparos por la soberanía nacional. Jonatás y Manuela es una novela que repite ciertos modelos narrativos, en cuanto a las situaciones episódicas que viven los personajes, las que proporcionan ciertas superficies textuales llenas de sabor local, de cotidianeidad sociocultural por las que transitan mujeres y hombres en posiciones binarias: negros contra blancos, amos contra esclavos, amantes contra esposas, blancas bellas contra negras feas. Es decir, se reproducen las propuestas que ya el romanticismo creó para los sujetos sociales, étnicos y culturales que ocupaban el espacio heterogéneo de las plantaciones esclavistas. Los signos y símbolos que indican el contacto intercultural entre dos mundos, el español y el africano, se representan a través de: el sacerdote que no respeta sus votos, el negrero cruel, el mayoral blanco y lujurioso, la criolla ardiente, la negra que traiciona a los suyos o el amo desapegado, la esposa que envejece mientras sirve de testigo a las escapadas sexuales del marido, y el esclavo que escapa y sufre castración como castigo. Las fiestas en los salones elegantes de Quito o Lima, los ritos de la santería, el ambiente misterioso y sensual de la "bajada" de las diosas africanas, la alteridad sincrética de las ceremonias bautismales, revelan el debilitamiento de las fronteras culturales, el surgimiento de la transculturación.

Esta gama de personajes blancos y negros de los que se prevén formas de conductas configuradas ya en el género de la novela antiesclavista refuerza las características dialógicas de este texto con otros textos. Jonatás y Manuela es una novela de denuncia, cuyos personajes encajan dentro de la categoría de buenos y malos, cuyas conductas se van concretando a partir de sus reacciones a situaciones o experiencias ligadas o marcadas por la marginación social que les toca vivir. La concreción de los discursos de estos personajes, desplazados del centro, se llena de trasnacionalidad y transgresión por verse llenados de lógicas discursivas "colonialistas", propias del siglo XIX. Esta lógica discursiva no solo permite a los personajes interpretarse a sí mismos y al mundo que les rodea, sino que nos hace posible un acercamiento hermenéutico a los diarios de Manuela "desde afuera",

\footnotetext{
${ }^{3}$ En 1993 apareció esta obra que recoge las cartas y diarios inétidos de ambos personajes con textos escritos por Elena Poniatowska, Miguel Bonasso, Carlos Alvarez y Heinz Dieterich. Pero esta edición de la editorial Diana, no ha sido la única que ha tratado de presentar los amores entre estos dos criollos. En 1975, Mercedes Ballesteros pronunció una conferencia, titulada "Manuela Saenz, el último amor de Bolívar", con motivo del Año Internacional de la Mujer. Dicha conferencia fue publicada por la Fundación Universitaria Española en 1976.
} 
evitándonos el peligro de observar desde el centro. La comprensión e interpretación de Chiriboga de los personajes históricos señala que ha mirado los lugares de enunciación construidos tanto por los sujetos en sí como por sus interpretadores.

Como género, la novela antiesclavista en el siglo XIX siguió el modelo de las novelas históricas, es decir, sirvió de documento político, en la cual se recopilaban acontecimientos que afectaban la vida de esclavos y esclavistas y que venían semantizados por las ideas y prejuicios del autor. Jonatás y Manuela retoma el tópico la esclavitud que está presente en las novelas antiesclavistas. Sin embargo, el elemento dialógico y discutidor que se establece entre este género y los clasificados como autobiográfico, biográfico, y epistolar, y su presentación renovadora, me hace agrupar la narración de Chiriboga dentro de las de "construcciones de géneros". Esta categoría se aplica,

[...] cuando los discursos, en lugar de reproducir narraciones hegemónicas, se hacen cargo de discutirlas y problematizarlas. Por "construcciones de géneros" entendemos laemergencia de formas de subjetividad que evidencian tensiones y discontinuidades con las narraciones hegemónicas. No son fijas, ni prescriptivas, implican más bien emergencias singulares, aisladas y particularizadas [...] no implican necesariamente subversión ni contrahegemonía, pero si alejamientos, desplazamientos, innovaciones con respecto a la narración hegemónica (Hernández, La seducción 58).

¿Que es lo que busca "aislar y particularizar" la novelista ecuatoriana? La respuesta me la da el propio título, el cual no es temático, como sucede habitualmente en el género antiesclavista, sino dialógico y en la cual se compilan informaciones históricas que remiten a diferentes personas, acontecimientos y lugares impactados por la vida y las acciones de estas dos mujeres. Sus historias están reguladas bajo un ordenamiento cronológico sin fecha, que presenta la particularidad de estimular nuestra conciencia para ver la otra gran historia, la historia nacional, desde otra perspectiva. Una vez satisfecha esta primera curiosidad me vuelco a la segunda, ¿cómo se produce el "aislamiento" de este discurso del propuesto en las narraciones hegemónicas? La respuesta nos la da el análisis de los dos principales personajes femeninos, quienes no se ven repartidos en la misma forma binaria y jerárquica con que se vieron fijados los personajes del mayoral, el amo, el sacerdote, BaLunda. Estos primeros personajes, incluyendo a veces a la propia $\mathrm{Ba}$ Lunda, la abuela de Jonatás, circulan socialmente y culturalmente bajo un discurso hegemónico, primero el africano y luego el español. Es decir, respetan o se ven obligados a acatar leyes y costumbres dictadas por relaciones sociales colonialistas.

Al igual que otras escritores latinoamericanos, Chiriboga está interesada en aislar historias del pasado ecuatoriano, en Manuela Saenz, pero no quiere escribir una novela histórica acerca de la relación amorosa entre ésta y Bolívar, y para evitarlo, la figura de EI Libertador es solamente anunciada. La propuesta narrativa de la escritora es la asimilación y la legitimación de escribir un discurso sobre la identificación social y cultural que surgió entre Jonatás, esclava e hija de esclavos y Manuela, hija ilegítima de un hacendado español. Desea crear espacio para las tensiones que entran en pugna cuando dos mujeres deciden no acatar el modelo que se establecía en el siglo XIX entre esclavas y amos, mujeres y hombres, ricos y pobres, hijos ilegítimos y legítimos, adúlteras y esposas. En esta propuesta narrativa 
se observa la ausencia de muchos datos cronológicos específicos, y no es hasta el final de la novela, después de aparecer la palabra "finn", que leemos la tabla genealógica de Simón Saenz de Vergara, el padre de Manuela. Este cuadro genealógico, histórico, real, que "existe fuera de la ficción", reclama el proceso investigador que la escritora llevó a cabo; es decir, nos remite a la autoridad del discurso, a los estudios hechos y a la preparación de la novela. Es, por parte de la escritora, una forma de articular que miró políticamente el estudio semantizado de muchas historias sobre Bolívar, y sobre todo los diarios de Manuela, pero que su construcción histórica - cultural se concentra en la ama y la esclava.

En Jonatás y Manuela se apela a la historia y se prepara al lector a una reacomodación de ésta a partir de un narrador omnisciente que mantiene control de lo que los personajes presentan o revelan. A primera vista, esta estrategia de tener un narrador omnisciente, que intuye el futuro de la criolla pero que se abstiene de traer a la luz la relación amorosa de Manuela y Simón, o hacer referencias al epistolario de ambos, pudiera ser interpretada como una falsa premisa, la que propone que la tópica del epistolario femenino, por estar lleno de recuerdos, premoniciones y emociones amorosas, puede resultar menos válida que la que nos presentaría la tópica biográfica. Pudiera implicar una aceptación de que la premisa de la tópica de la biografía, cuyo discurso tradicionalmente se considera "concreto" y poco subjetivo, es más adecuada porque no enfatiza el apego emocional del héroe hacia cosas que no estuviesen relacionadas con la victoria política o la hazaña guerrera. Esto implicaría que el discurso de Jonatás y Manuela correría acorde con un orden arbitrario y marginador propio del discurso patriarcal y ésta se limitaría a presentar el "sentido de la realidad" histórica adoptado tradicionalmente. Sin embargo, el hecho de que Chiriboga pusiera el nombre de la esclava primero y luego el de la criolla implica en sí un reordenamiento, una re-formulación subjetiva socialmente sexuada formulada por la de una escritora afrolatinoamericana que reta la interpretación de otros escritores al acercarse a la historia de estas dos mujeres.

Jonatás y Manuela es una novela escrita para desentrañar y exponer lo que muchos escritores ignoraron en sus escritos o lo de que, apresurados por recobrar la figura de Manuela, se refirieron de paso a Jonatás como "esclava", sin construir el imaginario social donde se movía la mujer negra y esclava en ese período. Esta narración expone que no se debe omitir la voz enunciadora y denunciadora de esta mujer negra, que se convirtió en "propiedad de otros" por el poder de hombres sin escrúpulos y gobiernos ansiosos de establecer una hegemonía sociopolítica, racial y cultural a nivel universal, y que si esto ocurre se legitima solamente el discurso histórico-hegemónico, cuya interpretación, como sabemos, ha sido marginadora de la mujer, del negro y del indio.

Por su fuerte posición de denuncia, el dibujo que de las dos mujeres se nos presenta, crea tensiones intertextuales con otras novelas o ensayos, y permite medir la distancia interpretativa que ocurre entre la armazón del texto multidimensional de la vida de Manuela y Jonatás y la que se construye o puede construir teniendo como único resorte el retrato evocativo que de estas dos mujeres se nos ofrece en las historias latinoamericanas. Chiriboga expone lo que puede ocurrir con discursos que aspiran a caer dentro de los de "construcciones de género" y se convierten a su vez en hegemónicos por verse atrapados en una producción discursiva socio-cultural que es patriarcal. Reconocemos a través de la novela, que si se marca a Jonatás con un solo nombre, el de ser sólo la "fiel esclava de 
Manuela", las tensiones que se suscitan a partir de la reclamación de la voz de Manuela Saenz quedan mediatizadas, pues se excluye la voz del otro sujeto marginado, el de Jonatás, quien también habla desde el proceso de exclusión e inclusión que denuncia la criolla. Definir o identificar a Jonatás con un solo adjetivo y verbo, "ser fiel", es desmantelar los sistemas de pronunciación y enunciado que se planeaban desmantelar y al final no se entra en ninguna pugna con otros discursos hegemónicos y poscoloniales.

Pero quién es Jonatás, esta figura subversiva, tan llena de ambigüedades que aparece citada en tan diversos textos y a quien algunos historiadores, afanados en la reconstrucción del la figura héroe de Bolívar olvidan, y otros, animados por recobrar la de Manuela, la acusan de haber desaparecido de la vida de la criolla "sin dejar rastro". " Esto es lo que parece deducirse de la ponencia de Mercedes Ballesteros, quien en su "rescate" de la figura marginada del Saenz, expresó que,

Para defenderse de la pobreza instaló un mísero ténducho, frecuentado por clientela de mala estofa: "Tobacco, English Spoken. Manuela Saenz", se leía sobre la puerta. En 1837, al cabo de un largo destierro, le ofrecieron un salvoconducto para regresar a su Ecuador nativo. Lo rechazó. Seguiría allí, en un confín del mundo, sola y olvidada [...] Sus esclavas se habían ido muriendo. La intrépida Jonatás desapareció sin dejar rastro (27).

No hay duda de que este discurso tenía el loable propósito de crear tensiones con respecto al discurso hegemónico de los historiadores de Bolívar. Sin embargo, notamos que aunque califica de intrépida a Jonatás, la mirada que se dirige a la esclava entraña un acercamiento categorizador que la disminuye como persona. La palabra "abandonar" remite a una ruptura engañosa, inesperada que afecta la vida de otro individuo porque crea un doble impacto: la ausencia física inesperada del otro y la conmoción emocional del verse traicionado. El que "abandona sin dejar rastro", es un ser sin escrúpulos y taimado que merece condena, o por los menos aborrecimiento. Por este motivo, y a pesar de las buenas intenciones de Ballesteros, su texto se convierte en hegemónico y marginador, por dos razones: primero, porque priva de voza Jonatás y segundo, porque asume que la esclava por su posición subalterna, regulada desde arriba, jerarquizada por las diferencias de clases y color, "debe" ser fiel. El texto, por lo tanto que pugna en su instancia de denuncia con relación a Manuela, es marginador en su plataforma de especificidad de valores sociales colectivos en cuanto a Jonatás. Escribe Ana María Amado,

Las relaciones que pueden establecerse entre narración hegemónica de género y construcción de género son las mismas que en cualquier otro orden de la organización sociocultural. Es

\footnotetext{
${ }^{4}$ Cito: En la Conferenca pronunciada por Ballesteros, la referencia a Jonatás aparece después de lo siguiente: "Seguiría allí, en un confín del mundo sola y olvidada. Porque también la condición de olvidada le fue impuesta. Luego veremos por qué. Sus esclavas se habían ido muriendo. La intrépida Jonatás desapareció sin dejar rastro. Sólo tenía a su servicio a la india Juana Rosa y a dos negriras huérfanas". Esta aseveración podría entenderse como si Manuela, quien se encontraba en una situación precaria, hubiera sido abandonada por todos, incluso por aquellos que debían haber permanecido fieles a ella y contrapone la acción de la negra a la de la indígena (27).
} 
decir, una construcción de género puede volverse narración hegemónica en un proceso histórico dado (La seducción 58). ${ }^{5}$

Jonatás ni desapareció ni abandonó a Manuela, todo lo contrario, como se puede leer en los datos recogidos acerca de la criolla durante su estancia en Perú. En "Biografía de Manuela Saenz", Carlos Alvarez Saá, uno de los investigadores del equipo peruano que descifró los manuscritos de la ecuatoriana escribe:

Al llegar noviembre de 1856, el puerto de Paita es asolado por una epidemia de difteria, la peste se propaga con tal virulencia que la mayor parte de la población sucumbe. En casa de Manuela, todas se enferman. Jonatás, quien fuera su sirvienta y compañera desde la niñez en travesuras y campañas militares muere el 23 de Noviembre de 1856. Poco después, Manuela Saenz cierra los ojos para siempre (Dieterich 279).

Alvarez, a diferencia de otros autores, ha evitado llamar a Jonatás esclava y la llama sirvienta, alterando así la relación social degradante e inhumana que implica la palabra esclavo y al hacerlo establece que la relación que compartían las dos mujeres tenía que ir un poco más allá de la que existía normalmente entre ama y esclava. No puede haber duda de que ya para el año 1856, Jonatás habría dejado de ser una "propiedad" de Manuela; serviría a su antigua ama en calidad de amiga, no de esclava. Por eso, referirse a Jonatás como esclava es reducir la figura de Manuela; es restarle dimensión socio-histórica a la emergencia de una alianza de poder que surge entre la hija bastarda y la niña esclavizada. Además, cómo se puede pensar que Manuela, una mujer que fue obligada a sufrir destierro, y quien para poder sobrevivir tuvo que pasar veinte años vendiendo cigarros y tabacos en una tenducho campestre, pudiera haber tenido dinero suficiente como para pagar esclavas.

Una vez que he destacado la alteración que Chiriboga quiere prestar al discurso hegemónico al situar el nombre de Jonatás, pasemos al relato y sus estrategias de producción textual. La atención del narrador se enfoca en la vida de tres mujeres negras, desde la salida de Ba-Lunda - la abuela de Jonatás - de África, hasta el enlistamiento final de la nieta Jonatás en las filas independentistas, en calidad de confidente y amiga de Manuela Saenz Aizpurú. El primer factor de suspenso en la novela nos lo ofrece la línea de intriga que se establece entre la vida de Ba-Lunda en Nigeria, libre y la de Ba-Lunda alias Rosa Jumandi, esclava en América. Se encara la experiencia africana de la primera protagonista antes de llegar a América, y conocemos que mucho antes de ser capturada tiene premoniciones de que algo malo le va a pasar, de qué sería "iba".

Desde su llegada al cortijo de Jabí, [el marido] su interés en colocar guardianes que la protegieran no fue producto de fatalismo ni de supersticiones, sino la intuición de que moriría esclava. Los linderos de la región estaban acechados por españoles confabulados con jefes negros, para capturar jóvenes y llevarlos de ibos a tierras lejanas. [...] Una madrugada, le acometió un pensamiento: sería iba. Al despertar, contó a su marido el

\footnotetext{
${ }^{5}$ En 1975, el proceso histórico que se vivía en el mundo hispano sobre todo, era darle voz a la mujer, traer la producción literaria femenina a las universidades, rescartar del abandono a figuras como Manuela. Los diarios de Manuela Saenz permanecieron inéditos por ciento cincuenta años.
} 
sueño: desde el fondo del rió había surgido un pez que, abriendo sus fauces, la absorbió $y$, en barriga del animal hizo un largo viaje del que fue imposible regresar, desterrada, se veía llorando inconsolable (12-13,énfasis mío). ${ }^{6}$

Se presenta pues a una Ba-Lunda pensando o "soñando en imágenes", es decir comunicando sus tensiones síquicas, en cuanto a una situación que ella percibe a través de su subconsciente; pero estas imágenes concebidas en sueños aluden a un mundo, a una realidad que ella desconoce a medias. Y digo a medias porque el mundo de la abuela de Jonatás, no es el mundo virgen del que se arrancaron los primeros negros esclavos, todo lo contrario. Esta es un Africa en la que se ha enseñoreado el miedo, el sufrimiento. Ba-Lunda sabe que Africa se ha entrañado a sí misma en dos mundos que se devoran entre sí: el de los comerciantes de esclavos y el de los africanos que piden protección a sus dioses. En uno, vive al lado de Jabí, contenta con su hija y protegida con sus "guardianes", y en el otro, se desvive presa del temor. Los ruidos, los olores que les trae el viento, los senderos en sombras no la llenan de alegría, sus sentidos le dicen que Africa está acechada por "confabuladores". Comenta el narrador que no importa cuántos guardianes la infeliz mujer ponga, su casa "se fue llenando de miedos".

Ella tenía el sonido de aquel pez en los oídos, y al relatar otra vez el sueño, fue como si estuviera viéndolo emerger del agua y aprehenderla. Ahora aseguraba que le había tocado la piel viscosa, con dientes parecidos a los del elefante [...] Fue llenando paulatinamente la casa con sus miedos (13).

Para enfatizar el subconsciente de Ba-Lunda se hacen alusiones específicas al pez y a la ballena, elementos simbólicos muy usados en la tradición literaria occidental para presentar las fronteras entre lo consciente y lo subconsciente (Cirlot ).

[...] the fish is a psychic being, or a 'penetrative motion' endowed with a heightening power concerning base matters-that is, in the unconscious. [...] the fish is the mythic Ship of Life, sometimes a whale, sometimes a bird, and at other times a fish or a flyingfish [...] (Dictionary of Symbolism 106).

Este viaje de Ba-Lunda y la imagen de verse devorada son una referencia intertextual al símbolo de la ballena - la cual representa el mundo, y la tumba del cuerpo, lo que se posee y se reprime o el abrazo de dos mundos opuestos (Cirlot 370), - y una alusión al barco negrero, en cuyas miasmáticas bodegas murieron las esperanzas de miles de esclavos de regresar a Africa. El sueño también nos dice de antemano dos cosas: primero, que Ba-Lunda sufrirá y segundo, que morirá en cautiverio. Frente a estas aseveraciones del narrador, lo único que nos falta saber es en cuáles circunstancias se producirán ambos hechos.

Sentado este conocimiento a priori, nos convertimos en testigos mudos de cómo el personaje trata de desechar sus temores, desatender los olores, desoír los ruidos; es decir, cómo trata de llevar una vida normal al lado de Jabí y a pesar de la presencia temida de los

\footnotetext{
${ }^{6}$ Todas las citas se refieren a Jonatás y Manuela.
} 
negreros. Pero Ba-Lunda no puede escapar y arriva a Ecuador como lo presintió, en calidad de "iba".

En la orilla miró a su hija [Nasakó], estaba dormida. Se propuso marginar el ruido, que creyó haberlo escuchado otras ocasiones. Al poner en el río el güiro vacío, cerca de la playa emergieron algunas burbujas; el agua giró en círculos concéntricos. Tomó del liquido en sus manos, lo llevó a la boca [...] más de pronto del centro de un chaoteo y su ruido surgieron dos manos que la cogieron por el cuello y la hundieron en las aguas. Al reflotar, el hombre la agarró por la cintura y le tapó la boca. En el forcejeo, intentó gritar, pero una bofetada le cortó las palabras. En su defensa, asestó un rodillazo en los testículos del intruso; él la soltó, aprovechó el instante para zambullirse y nadar. Pensó en su hija y braceaba desesperada; a poca distancia la seguía el extraño, cuya enorme dentadura quiso mostrar una sonrisa. [...] Con la niña en los brazos intentó subir por otro sendero; de pronto una parada súbita, un rastrillar en la cabeza, un golpe en el hombro, una soga en el cuello y una risa de júbilo: estaba enlazada (15-16).

A partir de ahí, el narrador prosigue a contándonos la vida de la joven Ba-Lunda desde el momento en que fue apresada al lado del río hasta su muerte muchos años después. El conjunto de elementos descriptivos que prepara Chiriboga ofrece la posibilidad de reconstruir a través de los elementos de la cotidianeidad, como son las faenas diarias de una mujer en el Africa de fines del siglo XVIII, la terrible tragedia de millones de africanos. A esta escena se unen otras más, incluyendo la reacción de Jabí, el marido, quien en su deseo de encontrar a $\mathrm{Ba}-L$ unda se entrega fútilmente a los negreros. Este personaje desaparece de la novela y dicha desaparición encierra connotaciones simbólicas en la novela. Jabí nunca hubiera tenido oportunidad de encontrar a los suyos, y por lo tanto, este personaje representa a aquellos esclavos que abandonados en diferentes puertos, o confinados a diferentes haciendas y lugares nunca abandonaron la esperanza de encontrar a sus familiares.

El impacto de este rapto y venta en la vida de esta familia se trae a la novela a partir de dos centros de "especulaciones", las formuladas por el marido dentro de su tierra natal y las de la mujer arrancada a la fuerza de la protección de los suyos.

Ba-Lunda duda del poder de sus dioses. ¿Por qué — se pregunta- si son tan poderosos, permiten separarla de Jabí? ¿Qué pecado cometí para que me castiguen de este modo? ¿O es mentira que todo lo pueden? (20).

Jabí, por su parte, desesperado, se muestra incrédulo ante la terrible verdad de que los negros se hubiesen confabulado con los blancos y vendieran a su esposa e hija simplemente para obtener dinero o por venganzas tribales. El desdichado personaje no puede encontrar descanso en ningún lado. La incredulidad abre paso al desasosiego y la desesperanza y se le ve preguntando por todas partes por su esposa e hija; en todas partes oye la misma irónica respuesta, que si no sabía que, "desde más de un año, los negociantes africanos tienen en la desembocadura del río, un lugar donde reúnen mujeres y hombres, que llegados a una Bahía, los meten en barcos que van al otro lado" (19).

El complejo de culpabilidad lo asalta hasta en sueños, y creer ver y oír los reproches de Ba-Lunda,

[la] vio encorvada a su mujer, bajo un sol de espinas, con un espeso sudor que le corría a borbotones por la frente, haciendo huecos y más huecos para sembrar cañas. Permanecía 
viva, todavía no se la habían cocido, pero estaba envejecida por el trabajo. [...] —Jabí por qué no me salvaste? Tú sabías que los blancos estaban cazándonos.

- ¿Quién habla [pregunta Jabí]

- Lo soñé, te lo dije, tú eres el culpable (24).

A través de estas especulaciones de los personajes, la escritora nos establece la conexión entre los acontecimientos en América y el individuo en Africa; nos hace explícitos las desastrosas repercusiones que tuvieron en el seno de la familia africana la cacería humana que se llevó a cabo a gran escala desde el siglo XVIII. Al mismo tiempo, aunque la angustia de los seres afectados por la esclavitud no es un tópico nuevo, Chiriboga lo retoma para presentar las tensiones y las contradicciones que pugnan entre testimonio y ficción cuando se quiere llevar adelante novelas de recreación histórica.

La trágica vida de Ba-Lunda toma seis capítulos, y en ellos el narrador llama a la joven africana unas veces Ba-Lunda y otras Rosa Jumandi, estrategia narrativa muy efectiva que persigue imponer una perspectiva socio-histórica al lector, del cual se quiere cooperación a la hora de leer el texto, y enfocar la herencia de Ba-Lunda en América en la figura de la nieta. Se aspira a que nosotros como lectores, tengamos plena conciencia de quiénes eran los antepasados de Jonatás, reconozcamos la distancia temporal e ideológica que hay entre el personaje de Ba-Lunda /Rosa y de Jonatás/ Nasakó.

La realidad que confronta Ba-Lunda en América la sume en tal grado de desesperación que sólo el ensueño la libraba de sus penas,

[Ba -Lunda] a pesar del encierro y el trabajo durante dieciseis años [...] creó en su mente un mundo antes desconocido, en el que se refugiaba. Para ella era como si se hubiera desmoronado la montaña y le cubriera el camino hacia la libertad, y su río Níger, en una creciente de invierno, arrasara todo a su paso, dejando sólo desolación. Prisionera de esta ideas, algunas veces no determinaba si era realidad o imaginación lo que le sucedía. [...] Sentía que era ella y no era al mismo tiempo, cierta y extraña al mundo que la envolvía y le cerraba los senderos Le fue familiar el olor del forastero que la cazó en el Alto Níger, aquel primer contacto [...] quería echarlo de su vigilia y de sus sueños, pero cada vez los sentía más férreamente adherido. [...] Trataba de no respirar para evitar aquel olor que, de tanto evocarlo, se le había impregnado. Sintió pánico al creer que se le había metido en la sangre el olor de los blancos. En ocasiones creía que, para llevar con éxito su venganza, debería ser como ellos (35).

Como vemos, tortuoso y largo es el proceso de adaptación que tiene que sufrir la esclava, pero decidida a crear lo mejor dentro de la peor situación, adopta nuevas estrategias, recuerda otras, y a los pocos meses de esclava pasa a conspiradora, y investida con esta nueva categoría social, se afana en reconocer los beneficios que el bautizo le puede ofrecer. BaLunda, la madre de Nasakó quiere aprender de esta Rosa Jumandi, la madre de Juana; quiere apoderarse de la personalidad taimada y engañosa que descubre en el negrero o en el mayoral, aspira a "ser como ellos", pues cree que sólo así podrá vencer a sus enemigos y regresar a Africa con su hija. Al mismo tiempo, la joven mujer está consciente de que mientras más se vuelva Rosa menos será Ba-Lunda; adivina que Rosa le hará menos real la nitidez de las fronteras entre Africa y América. Concederse a Rosa Jumandi, nombre que 
le pone el mayoral después de violarla, y que la ceremonia bautismal oficializa, sería perder la identidad de la africana Ba-Lunda. Batiéndose entre estas dos mujeres, la que fue y la que no quiere ser, transcurre la vida de la esclava, quien poco a poco va aprendiendo a crearse una nueva identidad para poder sobrevivir. Esta lucha interna hace que el personaje vaya tornándose en un figura taciturna y callada, se ensimisma en un silencio que no lograban romper ni sus amigas de infortunio. Muchas le pedían que les dijera su historia,

[...] pero ella no contestaba. Fue envolviéndola una soledad tan impenetrable que, cuando ellas [las amigas] contaban sus historias, ella silenciosa deslizaba sus dedos a contrapelo sobre el lomo del gato. En vano las amigas se esforzaban por conocer su origen y hacerle partícipe de sus conversaciones. Con el entrecejo fruncido, Ba-Lunda, ahora, Rosa, se enclaustraba cada día más en sí misma (40).

Lo que se observa en este episodio es el gran desafío intelectual y emocional que lleva a cabo Ba-Lunda, quien está consciente de que para poder sobrevivir tiene que adoptar nuevas estrategias. Se observa, asimismo, cómo se concientizan las tensiones que la crudeza de la realidad de ser esclava impusieron al personaje. Se nos revela su aprehensión de perder su identidad africana, y cómo trata de encontrar medios de resistencia nuevos, medios que retan la perspectiva hegemónica del "discurso nacional", que suele pintar a la esclavas sólo como víctimas, incapaces de retar las fuerzas que les oprimían. Esta presentación de BaLunda en sus primeros años en América como esclava y con una niña pequeña, es una prueba de que la novela de Chiriboga es una ruptura epistemológica con la ideología de la "historia" de Manuela y Jonatás contada desde los libros históricos, y por eso considero que el único lugar posible para situar este tipo de novela es dentro de las narraciones de "construcciones de género".

Al leerse la historia de Ba-Lunda notamos que hay una transformación del escenario social que presentan las novelas antiesclavistas, porque en la presentación de la abigarrada red de relaciones sociales que se llevan a cabo entre personajes, normas de valores impuestas y problemas que necesitan solución, comprendemos que para Ba-Lunda lo más importante es cuidar a la hija. Sus experiencias de querer escapar, pronto le enseñan que las posibilidades de convertirse en una cimarrona son limitadas, casi vedadas para las mujeres que tienen hijos pequeños. Esta verdad, sin embargo, ni merma sus deseos de resistencia ni la desaniman y frente a la dinámica socio-cultural que se desarrolla en la plantación, decide poner en práctica un plan para el futuro de su hija. Este plan ya no incluye el de la huida, pues sabe que los duros trabajos en el corte de caña han quebrantado su salud y que Nasako es muy joven para sobrevivir en el monte. Decide entonces modelar el carácter de la hija, quiere preservar en la memoria de Nasako el recuerdo del padre africano, y en su espíritu la herencia cultural africana. Intuye que la discontinuidad, la separación tendrán efectos negativos en Nasakó; está consciente de que para lograr dejarle dicha herencia cultural y familiar, es imprescindible que ella pueda permanecer al lado de la niña hasta que ésta por lo menos haya alcanzado la pubertad. Consciente de la situación en que se encuentran, deja a un lado el orgullo y oculta la violación, pero el sacrificio no termina ahí. Aún a sabiendas de que jamás volverá a ver al marido, no se enlaza amorosamente con ningún esclavo y reprime sus deseos sexuales. La joven madre sabe que si tiene más hijos las probabilidades de separación entre ella y Nasako aumentarían y podrían ser vendidas separadamente. 
Pero si no hay sensiblería gratuita en la caracterización que la escritora da a la lucha que ocurre en el espíritu de Ba-Lunda mucho menos la encontramos en la descripción de la muerte de la esclava. Como he señalado anteriormente, ya el narrador nos había anunciado que la mujer moriría esclava, sólo nos faltaba conocer los detalles . La muerte de Ba-Lunda ocurre un día después de que los esclavos intentando librarse de la esclavitud, decidieron aprovecharse de una ceremonia en el ingenio para suicidarse en masa. Los jesuitas atemorizados de que se produjese un pacto similar, deciden mandar el grupo de Ba-Lunda /Rosa y Nasako/ Juana a otra de sus haciendas. El pesar de ver morir a los suyos, el constatar lo baldío del sacrificio, la noticia de tener que dejar la hacienda y el temor de verse separada de Nasako son demasiadas emociones para la sufrida mujer, y Rosa/ Ba-Lunda muere de un ataque cardíaco. Comenta el narrador,

Los esclavos, a sabiendas de que estaban siendo enviados a otras destinatadoras de los jesuistas [...] alzaron voces de protesta [...] Rosa se dijo: ¿Qué haré si se llevan a mi hija a otra hacienda? ¿A dónde irá mi Nasako?; advirtió una contracción en el pecho; luego, un agudo estremecimiento que le cortó la respiración. Intentó llamar a la pequeña, pero su propósito devino resbalón y, finalmente caída. [...] Juana lloró al ver a su madre en el suelo. dos hombres armados la apartaron y uno de ellos la introdujo en un barracón. [...] Juana fue vendida a otra hacienda [...] (69)

A través de este pasaje, se observa que la escritora nos prepara para que aceptemos la realidad de la transculturación, y el nacimiento de una nueva identidad americana. Juana y Rosa son los nombres que sobrevivirán en América, planteamiento cultural que se confirma en los próximos capítulos. A raíz de la muerte de $\mathrm{Ba}$-Lunda los acontecimientos relacionados con Nasako Juana se precipitan; como la madre Juana crece en la esclavitud, se casa y después de haber perdido consecutivamente tres varones a causa de distintas enfermedades, nace Jonatás. Pero el deseo de Juana de nombrar a su hija con el nombre de Nasako Zansi, en honor de los abuelos y porque según ella "tenía algo de caballo", no pudieron impedir que "otros" bautizaran a la niña con el nombre de Jonatás. El nombre de Nasako se pierde también en la hija africana de Ba-Lunda, "quien creció sin preocuparse del pasado ni de lo que vendría en el futuro". La vida de Nasako Zansi - Jonatás se vio pronto invadida por los acontecimientos: primero un ataque de viruela que la dejó toda llena de cicatrices y sin cejas para toda la vida, y más tarde su venta y separación de la Juana. De esta forma, Nasako Zansi, la nieta de Ba-Lunda y Jabí, pasa a ser propiedad de don Simón cuando apenas tenía nueve años; el poderoso hacendado la bautiza con el nombre de Jonatás y le hace saber que permanecerá en la casa como esclava y compañera de Manuela, su hija bastarda.

La escena en el mercado de esclavos, en donde madre e hija son separadas, presenta por un lado, el desligamiento emocional de los nuevos compradores y futuros propietarios hacia los esclavos, y por el otro la carga emocional que sufren aquellos que temen verse separados, vendidos como animales al mejor postor. Los esclavos más arrojados emprenden la huida hacia el monte, entre ellos Juana, y Jonatás queda sola, encima de la plataforma mercantil. La forma en que Jonatás llega a manos de Manuela nos la relata el narrador. 
[Don Simón] Había ido río arriba a caza de una niña que fuera risueña, para criarla junto a su hija bastarda, de rostro siempre abatido, cuya infancia discurría en su hacienda. [...] El blanco observó detenidamente a la negrita, no era lo que buscaba, juguetona pero fea y ñarusa; no valía cien pesos [...] Continuó husmeando el grupo [...] intento alejarse de la plaza [...] pero le pareció que la chiquilla era muy despierta, no pensó más y antes de que otro pronunciara su oferta pagó el valor vociferado (77).

Según se lee en los datos biográficos de Manuela, ésta tendría unos siete años cuando su padre le entregó a Jonatás como esclava. La llegada de la niña esclava cambia la vida de la criollita, quien pronto se ve envuelta en diversos juegos, incluso el de la guerra, en los que los "musis", los negros, como diversión mataban a los españoles. Por las noches, ambas acuden a los barracones y escuchan los relatos de aquellos que seguían recordando a familiares e hijos abandonados a la fuerza; conocen de los castigos y lloran frente al infortunio humano. Allí, en los barracones, las viejas esclavas narraban sus historias, impulsadas por "el anhelo de que no se perdieran con el paso del tiempo" (84).

La ama y esclava se convierten en una pareja inseparable, Manuela malhumorada y triste, Jonatás juguetona y dominante; la criolla abatida, la esclava rencorosa. Los juegos a matar españoles van cobrando forma y poco a poco la realidad de la lucha por la independencia ecuatoriana va tomando forma e infiltrándose en el corazón de las adolescentes. Juntas van creciendo, Jonatás enseñará a Manuela montar a caballo, vestirse con colores llamativos, incursionar de noche, hablar con los esclavos; pero la esclava no se detiene allí, sino que introduce a la criolla en el mundo sincrético de la santería. Jonatás aprende de las volutas de humo de tabaco que el arreglo matrimonial que no pudo lograr la madre de Manuela, le está reservado a la desinhibida hija; le vaticina los viajes con el ejército libertador, su ascensión en la carrera militar, y los altos grados militares con que se verá engalanada, y sobre todo la pasión que le unirá a Simón Bolívar y finalmente el destierro que le espera. De Jonatás aprenderá a endurecer el olvido, a no cejar en sus empeños, a no ser amargada. Ahí estaba Jonatás, como ejemplo de perseverancia siempre buscando a la madre y llenando la hacienda de Catahuango con sus risas y maledicencias. Manuela al lado de Jonatás crecerá física y emocionalmente saludable.

Por otra parte, Manuela le dará a Jonatás la hermana que no tuvo, la amiga que sabe escuchar, la voz que le permite sosegar su odio y encontrar que no todos los blancos merecían desprecio. Manuela enseñara a leer a la indomable Jonatás, la protegerá de las sospechas de los colonos, le ayudará a vendar al herido, obtener dinero, hablar el español, a dominar el miedo de verse vendida, como lo fue la abuela y como lo fue la madre, a confiar que no morirá en el camino, sola, como ocurrió con su abuela Ba-Lunda. Nace esa gran relación que las llevará a la historia y haría sus nombres transnacionales no como esclava y ama sino como amigas y compatriotas.

En los capítulos finales aprendemos que Juana/Nasako y Jonatás/Nasako Zansi se encuentran, los papeles se han trocado: la madre, la hija de Ba-Lunda la esclava africana, persigue a los cimarrones, en cambio la nieta, la "americana" los libera. Los caminos de la madre y la hija se alejan para siempre mientras que lo de Jonatás y Manuela se unen. Jonatás no pudo leer en las volutas del tabaco hasta que punto alcanzaría el "destierro" a Manuela, tampoco pudo predecir la larga e intencionada omisión de la misma en la historia de su 
patria. Pero lo que sí pudo adivinar es que para hablar de Manuela habría que hablar de Jonatás/Nasako Zansi/Jonatás le augura a Manuela Saenz que,

[...] subirá y bajará, irá y volverá, visitará palacios, será condecorada con la Orden de la Divisa por un hombre alto y blanco que está siempre junto a Rosita Campuzano. ${ }^{7}$ Conocerá el lujo y lo disfrutará, sufrirá miserias y una larga enfermedad, verá jinetes saltando veloces en los llanos, se matarán, se traicionarán, hombres sabios y desinteresados y hombres estúpidos, ingratos y traidores. [...] aparece un largo túnel de sombras que devoran multitudes, sombras que proyectan luces, pero Manuela está allí, aferrada a un rollo de proyectos; sombras que flamean guiñapos de gloria. La choteña escupe migas de cigarros en una escudilla, sonrie a Manuela, a sabiendas de que seguirá junto a ella (159, énfasis mío).

El credo antirracista, las alusiones a los campos de batalla, la movilización de los negros esclavos a las filas revolucionarias y nacionalistas, los personajes multidimensionales, aun cuando son presentados en evocaciones futuristas, como los de San Martín y Bolívar, pero sobre todo la exposición de quiénes, cómo y por qué se formó esta gran amistad entre estas dos mujeres, hacen que podamos calificar a Jonatás y Manuela como un intento exitoso por parte de Chiriboga de escribir una "novela nacional". Esta se ha desarrollado sobre una recreación histórica de tensiones que surgen por la alianza antirracista y nacionalista de muchas amas y esclavas; de tensiones que surgen en base a una acción colectiva entre mujeres y hombres. En Jonatás y Manuela las voces de los personajes, su etnicidad, clase social e ideología son las que recrean las tensiones que sirven para contrarrestar la perspectiva hegemónica que se brindan en las historias sobre El Libertador o acerca de la "libertadora del libertador". Chiriboga ensaya una proposición nueva sobre la vida de Manuela Saenz, en la cual se admite que nacionalismo, raza y sexualidad pueden remitir a una historia pero no a todas las "historias".

\section{Bibliografia}

Ballesteros, Mercedes. Manuela Saenz. El último amor de Bolívar. Alcalá: Fundación Universitaria Española, 1976.

Chiriboga, Argentina. Jonatás y Manuela. Ecuador: Abrapalabra, 1994.

Dieterich Steffan, Heinz et al. (eds.). Patriota y amante de Ud. Manuela Saenz y el Libertador. México: Editorial Diana, 1993.

Frank, Waldo. Birth of a World: Bolivar in Terms of his People. Boston: Houghton Mifflin Company, 1951.

\footnotetext{
${ }^{7}$ Aquí la escritora se refiere a San Martín, quien estaba ligado emocionalmente con la limeña Rosa Campuzano, otra gran figura revolucionaria. Estos encuentros fueron posibles porque Manuela después de casada con James Thorne le acompañó a vivir a Lima, en donde siguió luchando en aras de los ideales indepedentistas. En reconocimiento de sus hazañas, entre otras la de lograr que el batallón "Numancia" pasara de las filas españolas a las revolucionarias, la quiteña obtiene la "Orden de Caballeresca del Sol" de manos del Protector limeño, San Martín. Esto según los historiadores provocó los celos de muchos capitanes, entre ellos los de Santander, el que más tarde hostigaría con sus celos, deprecios e iras a Bolívar y Manuela.
} 
Hernández Monroy y Manuel E. Medina (eds.). La seducción de la cultura: Los discursos de la cultura hoy. [1996]. México: Impreso Johny, 1997.

Ludwig, Emil. Bolivar, The Life of an Idealist. Emil Ludwig, trad. Londres: W. H. Allen, 1947.

Salcedo-Bastardo, J. L. Bolivar: A Continent and its Destiny. Annella McDermontt, trad. Richmond: The Richmond Publishing Co., 1977.

Sociedad Bolivariana de Venezuela. Escritos del Libertador. Tom. 3. Documentos Particulares. Caracas, 1967. 
